\section{PV BATTERIES AND CHARGE CONTROLLERS: Technical Issues, Costs, and Market Trends}

\author{
R.L. Hammond \& J.F. Turpin: Arizona State University East, Mesa, AZ 85206 \\ G.P. Corey \& T.D. Hund: Sandia National Laboratories, Albuquerque, NM 87185 \\ S.R. Harrington: Consultant, Albuquerque, NM 87120
}

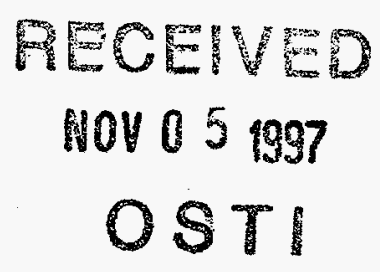

\begin{abstract}
A survey of US system integrators, charge controller manufacturers, and battery manufacturers was conducted in 1996 to determine market and application trends. This survey was sponsored by the US Dept. of Energy. Results from 21 system integrators show a 1995 PV battery sales of $\$ 4.76$ million. Using the survey results, a top down market analysis was conducted with a total predicted US battery market of $\$ 34.7$ million and a world wide market of US\$302 million. The survey also indicated that $71 \%$ (of dollars) were spent on VRLA and $29 \%$ on flooded lead-acid batteries. Eighty percent of charge controllers were "ON-OFF, vs. PWM or constant voltage.
\end{abstract}

\section{INTRODUCTION}

The survey included three separate segments tailored to the following groups:

A. PV system integrators

B. PV charge controller manufacturers

C. Battery manufacturers

The overall purpose of the survey was to:

- quantify the market for batteries shipped with (or for) PV systems in 1995,

- quantify the PV market segments by battery type and application of PV batteries,

- characterize and quantify the charge controllers used in PV system,

- characterize the operating environment for energy storage components in PV systems and

- $\quad$ estimate the PV battery market for the year 2000

In January 1996 Survey A was sent to PV System Integrators (11 large and 18 small); Survey $B$ was sent to 10 Battery manufacturers; Survey $C$ was sent to 10 Charge Controller manufacturers.

Responses to the three surveys were:

Survey A-Large: 8 responses from 11 inquires (73\%)

Survey A-Small: 13 responses from 18 inquires $(72 \%)$

Survey B: 9 responses from 10 inquiries (90\%)

Survey C: 8 responses from 10 inquiries $(80 \%)$

Responses for each survey $(\mathrm{A}, \mathrm{B}$, and $\mathrm{C})$ were consolidated

10/20/97 8:32 AM C:My Documentsitomtom.rtf and highlights are presented herein.

\section{SURVEY A, SYSTEM INTEGRATORS}

Survey A was segmented into four parts: 1) Battery Sales Data, 2) Battery Information Needed For PV System Design, 3) PV System Operating Conditions, and 4) Hybrid System Issues.

\section{Part 1. Battery Sales Data: Market Analysis}

The majority of results presented in Part 1 were based solely on summary results from the 21 System Integrators that responded to the survey. These summary results are, to a large extent, representative of the worldwide market. However, the summary results do not provide a means to estimate total PV battery sales for either the US market or the worldwide market. In order to put the data from Part 1 in perspective, a Top-Down Market Analysis was developed to quantify the volume of batteries installed in PV systems.

The top down analysis is based on a rule of thumb ${ }^{1}$ which provides an estimate of the number of batteries used for each 50 watts (peak) of modules used. Since the number of PV watts shipped each year (both US and worldwide) is well known and published by recognized PV marketing experts, it is a straight forward process to estimate the total number of batteries installed in PV systems each year.

Worldwide PV module shipments in 1995 were approximately 78 megawatts (MW) ${ }^{2}$, with about $67 \mathrm{MW}$ being used in stand-alone applications (about $11 \mathrm{MW}$ were used in

${ }^{1}$ The widely accepted rule of thumb is that for every 50 watts (peak) of PV modules used in a PV system, approximately 1.2 $\mathrm{kW}$ of battery is used (e.g., one 12V, 100 Ah battery). The authors of this report estimated that the uncertainty of this rule is $+/-20 \%$.

2 Based on averages of data from conversations with Bob Johnson of Strategies Unlimited (May 1996), and Paul Maycock of PV News, February 1996. Johnson and Maycock are two of the leading PV industry experts who have provided technology and market reports (including historical and forecasted PV sales data) for about two decades. 


\section{DISCLADMER}

Portions of this document may be illegible in electronic image products. Images are produced from the best available original document. 


\section{DISCLAIMER}

This report was prepared as an account of work sponsored by an agency of the United States Government. Neither the United States Government nor any agency thereof, nor any of their employees, makes any warranty, express or implied, or assumes any legal liability or responsibility for the accuracy, completeness, or usefulness of any information, apparatus, product, or process disclosed, or represents that its use would not infringe privately owned rights. Reference herein to any specific commercial product, process, or service by trade name, trademark, manufacturer, or otherwise does not necessarily constitute or imply its endorsement, recommendation, or favoring by the United States Government or any agency thereof. The views and opinions of authors expressed herein do not necessarily state or reflect those of the United States Government or any agency thereof. 
Preprint: $26^{\text {th }}$ IEEE PVSC 29 September - 03 October 1997

grid-connected and consumer ${ }^{3}$ applications). Water pumping, a segment of the stand-alone market, often does not use batteries, so the $67 \mathrm{MW}$ will be adjusted downward to 64 MW, which represents PV module sales in systems that included batteries. Using the rule of thumb of one $12 \mathrm{~V}-100$ AH battery (i.e., $1.2 \mathrm{kWh}$ ) for each 50 watts of PV modules, the 1995 PV battery sales can be calculated:

- The total worldwide sales of PV batteries in 1995 was $(64 \mathrm{MW} / 50 \mathrm{~W})^{*} 1.2 \mathrm{kWh}=1,536,000 \mathrm{kWh}$.

Additional batteries were sold during 1995 to replace batteries that reached end-of-life in existing PV systems. Assuming a typical battery life of 5 years and that all PV system batteries installed in 1990, 1985, and 1980 were replaced $(934,000+291,000+200,000 \mathrm{kWh})$, then a total of $1,425,000 \mathrm{kWh}$ of batteries were replaced in 1995 .

The total of new-system batteries in $1995(1,536,000$ $\mathrm{kWh})$ plus the replacement batteries $(1,425,000 \mathrm{kWh})$ equals 2,961,000 kWh of PV system battery sales. From Table 2-3, the average cost per $\mathrm{kWh}$ in 1995 was $\$ 102$ per $\mathrm{kWh}$ (wholesale).

- The worldwide wholesale value for PV batteries shipped in 1995 was $\$ 302$ million.

The approximations which went into this calculation will limit the accuracy to about \pm 25 percent, so that an appropriate range for wholesale dollar value would be $\$ 226$ to $\$ 378$ million.

It is estimated that about 11.5 percent $^{4}$ of the total 64 MW of stand-alone PV were installed in the US in 1995. Therefore, total PV battery sales in the US were $11.5 \% * 2,961,000 \mathrm{kWh}$ or $340,515 \mathrm{kWh}$ (or about $11.5 \% * \$ 302$ million $=\$ 34.7$ million $)$.

- This indicates that the 21 System Integrators control about $\$ 4.76$ million $^{5} / 34.7$ million $=14$ percent of the US PV battery market (in terms of dollar sales).

Using the same methodology to calculate the newly installed capacity each year (not counting replacement batteries, it is estimated that:

- Approximately $10,519,000 \mathrm{kWh}$ of batteries are currently installed in PV systems worldwide.

The approximations used for these calculations limit the accuracy to about \pm 25 percent.

3 Consumer applications: small "expendable" products such as solar powered calculators, toys, and walk lights ( $<$ five watts peak).

${ }^{4}$ Based on estimates of 12.8 percent by Paul Maycock (PV News) and 10.6 percent by Bob Johnson (Strategies Unlimited) during telephone conversations November 1, 1996.

5 see Table 3 Totals For All Batteries.

\section{Summary Of Results From The 21 System Integrators}

All battery sales reported (Tables 1, 2, and 3) were for leadacid batteries (there were no nickel-cadmium batteries reported). The total cost of batteries purchased by the 21 System Integrators in 1995 was $\$ 4.8$ million at a unit volume of 26,308. The "top-down" market analysis showed the total worldwide PV battery shipments in 1995 to be approximately $\$ 302$ million and 2,961 MWh. This is equivalent to about 2 million $12 \mathrm{~V}-100 \mathrm{AH}$ batteries. The US share of this market was approximately 11.5 percent or 34.7 million dollars $(340,515 \mathrm{kWh})$. The 21 System Integrators supplied about 14 percent of the 1995 US PV battery market in terms of wholesale dollars. One conclusion that may be drawn from the analysis is that many US end users buy their PV batteries directly from a battery supplier and not from a system integrator.

Seventy-one percent of the dollars were spent on valveregulated batteries (Table 3 ), and valve-regulated batteries cost 88 percent more than flooded-vented batteries per $\mathrm{kWh}$ $(\$ 128 / \mathrm{kWh}$ Vs $\$ 68 / \mathrm{kWh})$. The use of valve regulated batteries increased by 145 percent from 1991 to 1995 , while the use of flooded-vented batteries increased by 117 percent in units, but decreased by about 25 percent in dollars.

The eight Large System Integrators sold 78 percent of the total units (Large plus Small Integrators) and captured 88 percent of the total dollars (Large plus Small Integrators). Small System Integrators sold 16 percent of the valveregulated units and 33 percent of the flooded-vented units. The primary applications for valve-regulated lead-acid (VRLA) batteries were telecommunications $(40 \% 6)$, telemetry $(13 \%)$, and lighting (9\%)(Table 4). Approximately 85 percent of all batteries reported in the categories of telecommunications, telemetry, and lighting used VRLA batteries. Thirty percent of all flooded-vented batteries were used in hybrid systems (as opposed to 89 percent of all hybrid applications used floodedvented batteries; see Table 5), 31 percent in telecommunications, and 17 percent in remote homes. The preference for VRLA batteries or flooded-vented batteries depended to a large extent on the market segment that the battery serves.

Valve-regulated batteries are heavily skewed toward $12 \mathrm{~V}$ modules $(60 \%) ; 35$ percent were $6 \mathrm{~V}$ modules, and only 5 percent were $2 \mathrm{~V}$ cells. Flooded batteries were skewed toward $2 \mathrm{~V}$ cells $(45 \%) ; 42$ percent were $6 \mathrm{~V}$ modules, and 12 percent were $12 \mathrm{~V}$ modules.

In terms of amp-hour size, valve-regulated batteries were grouped in the 100-400 AH bin for $6 \mathrm{~V}$ modules and the 0-200 $\mathrm{AH}$ bin for the $12 \mathrm{~V}$ modules. Flooded batteries were more broadly distributed in the 600-3,000 AH range at $2 \mathrm{~V}, 200-400$ $\mathrm{AH}$ at $6 \mathrm{~V}$, and $1400-1800 \mathrm{AH}$ at $12 \mathrm{~V}$.

\footnotetext{
$6_{i . e .,}$ the percentage of $\mathrm{kWh}$ for all valve-regulated batteries.
} 
Table 1. Valve-Regulated Lead Acid (VRLA) Batteries

\begin{tabular}{|l|rr|rr|rrr|}
\hline \multirow{2}{*}{ MANUFACTURER } & \multicolumn{7}{|c|}{1995} \\
\cline { 2 - 7 } GNB & \# of Units & $\%$ of \# & $\$$ (Wholesale) & $\%$ of $\$$ & kWh & $\%-k W h$ & $\$ / k W h$ \\
DEKA & 3,901 & $23 \%$ & $\$ 2,240,352$ & $66 \%$ & 14,234 & $54 \%$ & $\$ 157$ \\
JCI & 6,827 & $41 \%$ & $\$ 645,285$ & $19 \%$ & 6,746 & $25 \%$ & $\$ 96$ \\
CONCORD & 2,704 & $16 \%$ & $\$ 245,191$ & $7 \%$ & 3,073 & $12 \%$ & $\$ 80$ \\
SONNENSCEIN & 1,737 & $10 \%$ & $\$ 156,226$ & $5 \%$ & 1,661 & $6 \%$ & $\$ 94$ \\
POWERSONIC & 1,223 & $7 \%$ & $\$ 73,846$ & $2 \%$ & 459 & $2 \%$ & $\$ 161$ \\
MISC & 177 & $1 \%$ & $\$ 15,670$ & $0 \%$ & 98 & $0 \%$ & $\$ 160$ \\
TOTAL & 277 & $2 \%$ & $\$ 14,212$ & $0 \%$ & 253 & $1 \%$ & $\$ 56$ \\
\hline
\end{tabular}

Table 2. Flooded-Vented Lead-Acid (FVLA) Batteries

\begin{tabular}{|c|c|c|c|c|c|c|c|}
\hline \multirow[b]{2}{*}{ MANUFACTURER } & \multicolumn{7}{|c|}{1995} \\
\hline & \# of Unit & $\%$ of $\#$ & \$ (Wholesale) & $\%$ of $\$$ & $\mathbf{k W h}$ & $\%-k W h$ & $\$ / \mathbf{k W h}$ \\
\hline CEAC (France) [1] & 1,84 & $19 \%$ & $\$ 318,703$ & $23 \%$ & 4,182 & $21 \%$ & $\$ 76$ \\
\hline C\&D & 76 & $8 \%$ & $\$ 271,872$ & $20 \%$ & 3,533 & $18 \%$ & $\$ 77$ \\
\hline TROJAN & 2,63 & $28 \%$ & $\$ 173,364$ & $13 \%$ & 4,174 & $21 \%$ & $\$ 42$ \\
\hline GNB & 18 & $2 \%$ & $\$ 168,119$ & $12 \%$ & 1,871 & $9 \%$ & $\$ 90$ \\
\hline IBE & 80 & $9 \%$ & $\$ 150,904$ & $11 \%$ & 1,641 & $8 \%$ & $\$ 92$ \\
\hline EXIDE & 1,68 & $18 \%$ & $\$ 116,950$ & $9 \%$ & 2,244 & $11 \%$ & $\$ 52$ \\
\hline EAST PENN & 62 & $7 \%$ & $\$ 80,448$ & $6 \%$ & 957 & $5 \%$ & $\$ 84$ \\
\hline US BAT & 80 & $8 \%$ & $\$ 71,740$ & $5 \%$ & 1,203 & $6 \%$ & $\$ 60$ \\
\hline PACIFIC CHLORIDE & 3 & $0 \%$ & $\$ 16,810$ & $1 \%$ & 187 & $1 \%$ & $\$ 90$ \\
\hline MISC & 8 & $1 \%$ & $\$ 1,150$ & $0 \%$ & 20 & $0 \%$ & $\$ 58$ \\
\hline TOTAL & $\overline{9,46}$ & $100 \%$ & $\$ 1,370,060$ & $100 \%$ & 20,012 & $100 \%$ & $\$ 68$ \\
\hline
\end{tabular}

Table 3. Total For All Batteries

\begin{tabular}{|c|c|c|c|c|c|c|c|}
\hline \multirow[b]{2}{*}{ TECHNOLOGY } & \multicolumn{7}{|c|}{1995} \\
\hline & \# of Unit & $\%$ of $\#$ & \$(Wholesale) & $\%$ of $\$$ & kWh & $\%-k W h$ & \$/kWh \\
\hline VALVE-REGULATED & 16,84 & $64 \%$ & $\$ 3,390,782$ & $71 \%$ & 26,524 & $57 \%$ & $\$ 128$ \\
\hline FLOODED-VENTED & 9,46 & $36 \%$ & $\$ 1,370,060$ & $29 \%$ & 20,012 & $43 \%$ & $\$ 68$ \\
\hline TOTAL & 26,30 & $100 \%$ & $\$ 4,760,842$ & $100 \%$ & 46,536 & $100 \%$ & $\$ 102$ \\
\hline
\end{tabular}

Table 4. Total For All Batteries kWh By Application(100\% by Technology) ${ }^{7}$

\begin{tabular}{|l|rrrrrrrrr|r|}
\hline TECHINULGY & RH & TC & TC & TIV & L & W & H & V & UKIV TOTALS \\
\hline VALVE-REGULATED & $7 \%$ & $6 \%$ & $34 \%$ & $13 \%$ & $9 \%$ & $2 \%$ & $3 \%$ & $3 \%$ & $23 \%$ & $100 \%$ \\
FLOODEDVENTED & $17 \%$ & $2 \%$ & $29 \%$ & $1 \%$ & $2 \%$ & $2 \%$ & $30 \%$ & $13 \%$ & $4 \%$ & $100 \%$ \\
\hline TOTAL & $11 \%$ & $4 \%$ & $32 \%$ & $8 \%$ & $6 \%$ & $2 \%$ & $15 \%$ & $7 \%$ & $15 \%$ & $100 \%$ \\
\hline
\end{tabular}

Table 5. Total For All Batteries; kWh By Application (100\% by Application)

7 H=Hybrid; L=Lighting; RH=Remote Home; TM=Telemetry; TC<=telecommunication systems less than 200 W(peak) of PV; TC $>=$ telecommunication systems greater than $200 \mathrm{~W}$ (peak) of PV; UKN=Unknown; V=Village Power; W=Water Pumping 
Preprint: $26^{\text {th }}$ IEEE PVSC 29 September - 03 October 1997

\begin{tabular}{|c|c|c|c|c|c|c|c|c|c|c|}
\hline TECHIVOLTOGY & RH & TC< & ICs & TIV & $\mathbf{L}$ & $W$ & H & & JK & TOIA \\
\hline VALVE-REGULATED & $35 \%$ & $81 \%$ & $61 \%$ & $94 \%$ & $85 \%$ & $59 \%$ & $\Pi 1 \%$ & $23 \%$ & & \\
\hline FLOODED-VENTED & $65 \%$ & $19 \%$ & $39 \%$ & $6 \%$ & $15 \%$ & $41 \%$ & $89 \%$ & $77 \%$ & & \\
\hline OAAL & $100 \%$ & $00 \%$ & $100 \%$ & $100 \%$ & $100 \%$ & $100 \%$ & $100 \%$ & $100 \%$ & $0 \%$ & \\
\hline
\end{tabular}


Part 2. Battey Information needed for PV System Design

This part of the survey asked Integrators what information they needed from the battery manufacturer in order to properly design PV systems with optimum performance and minimum life-cycle cost. Integrators ranked 29 parameters in terms of importance ( $1=$ Essential, $2=$ Useful, $3=$ Not Important). The first 20 parameters were ranked between 1.0 and 2.0 (averages for all 21 Integrators). The parameter ranked most important was "Cost".

\section{Part 3. PV System Operating Conditions}

Part 3 profiles the Integrators' application of PV hardware, their approach to PV system design, and the environment into which PV systems are placed.

Integrators reported that 80 percent of their charge controllers use an ON-OFF algorithm. The ON-OFF algorithm is by far the most difficult charge management algorithm for which to define voltage set points; battery manufacturers rarely, if ever, specify voltage set points for ON-OFF algorithms. This difficulty was emphasized by a battery manufacturer:

...Listen to the battery industry when we tell you that we need constant voltage regulators, higher endvoltage limits, and higher limits for low-voltage disconnects.

About 60 percent of integrator respondents use temperature compensated voltage regulators in their charge controller systems. By comparison, 88 percent of charge controller respondents felt that temperature compensation was either vital or important.

\section{Part 4. Hybrid System Issues}

Hybrid systems are stand-alone systems with two or more types of power generating sources, one of which is photovoltaics. The purpose of Part 4 was to identify unique characteristics and requirements of hybrid systems.

Forty-eight percent of the Small Integrators' business was hybrid systems, compared to 16 percent for Large Integrators. This may be due to the fact that Small Integrators provide many PV systems for remote homes, which often use a backup generator.

The majority $(52 \%)$ of hybrid systems batteries are flooded-vented lead-acid with antimony additive to the plates. None of the Integrators used flooded-vented batteries with calcium additive to the plates. Forty-eight percent of the batteries were VRLA.

\section{SURVEY B. BATTERY MANUFACTURER SURVEY}

This survey was designed to a) collect information regarding contacts and products that would be of interest to the PV industry and b) to determine what information that battery manufacturers needed from the PV industry. Nine of the ten battery manufacturers that received the three page questionnaire responded.

None of the nine respondents indicated that they had an "Application Guide for PV Customers" available at the time that the survey was submitted. However, four indicated that they will have an application guide available by the end of 1996.

\section{SURVEY C. CHARGE CONTROLLER MANUFACTURERS}

Two of the eight respondents had about 55 percent of the US unit and dollar volume in 1995 (Table 6). On the other end of the scale, two manufacturers had less than 2 percent of the market. A 203 percent growth rate in unit volume was projected for 1996 by the respondents

Manufacturers answered with one YES and seven NOs to the question "Do you receive adequate information from battery manufacturers regarding the performance of batteries in PV Systems?"

Table 6. Charge Controller Market

\begin{tabular}{|c|c|c|c|c|c|c|}
\hline & \multicolumn{2}{|c|}{ Unts, 1995} & \multicolumn{2}{|c|}{ Dolar Sales, ys } & \multicolumn{2}{|c|}{ Projected Unts } \\
\hline Mig. & Tnits & \%ofTodal & $\mathbf{S}$ & \%of Total & $19 \%$ & 9695 \\
\hline $\mathbf{A}$ & 75 & $0 \%$ & $\$ 13,925$ & $0 \%$ & 200 & $267 \%$ \\
\hline $\mathbf{B}$ & 285 & $1 \%$ & $\$ 54,150$ & 1\% & 1,590 & $558 \%$ \\
\hline $\mathbf{C}$ & 1,054 & $3 \%$ & $\$ 330,362$ & $6 \%$ & 1,270 & $120 \%$ \\
\hline $\mathbf{D}$ & 5,375 & $13 \%$ & $\$ 512,250$ & $10 \%$ & 6,335 & $118 \%$ \\
\hline $\mathbf{E}$ & 7,000 & $17 \%$ & $\$ 717,500$ & 14\% & 17,550 & $251 \%$ \\
\hline $\mathbf{F}$ & 4,734 & $11 \%$ & $\$ 800,790$ & $15 \%$ & 25,000 & $528 \%$ \\
\hline $\mathbf{G}$ & $1,230^{\circ}$ & $3 \%$ & $\$ 1,019,850$ & $20 \%$ & 4,950 & $402 \%$ \\
\hline $\mathbf{H}$ & 21,431 & $52 \%$ & $\$ 1,758,300$ & $34 \%$ & 26,780 & $125 \%$ \\
\hline ToIaIS & 41,184 & $100 \%$ & $55,217,127$ & $100 \%$ & 86,675 & $203 \%$ \\
\hline $\mathrm{XISQ1}$ & & & & & & \\
\hline
\end{tabular}

\section{CONCLUSIONS AND RECOMMENDATIONS}

\section{The Survey}

The survey provided: a) quantification and characterization of batteries and charge controllers used in PV systems, b) characterization of the operating environment in which batteries and charge controllers are used, and c) feedback from PV system integrators, battery manufacturers, and charge controller manufacturers defining what information each needed to optimize PV energy storage systems.

Survey respondents identified areas of focus by each of the three industries (PV System Integrators, Battery Manufacturers, and Charge Controller Manufacturers) in which they would like Sandia National Laboratories' (SNL) assistance. The high priority areas identified were: a) assist in the development of application guides or notes, b) assist in the characterization of batteries for PV data sheet values, c) provide technical liaison between the PV and battery industries and, d) perform surveys to define the market. 